\title{
Reforming Madrasa Education in Pakistan; Post 9/11 Perspectives
}

\author{
Ms Fatima Sajjad
}

\begin{abstract}
Pakistani madrasa has remained a subject of intense academic debate since the tragic events of $9 / 11$ as they were immediately identified as one of the prime suspects. The aim of this paper is to examine the post $9 / 11$ academic discourse on the subject of madrasa reform in Pakistan and identify the various themes presented in them. This paper also seeks to explore the missing perspective in this discourse; the perspective of ulama; the madrasa managers, about the Western demand to reform madrasa. This study is based on qualitative research methods. To evaluate the views of academia, this study relies on a systematic analysis of the post 9/11 discourse on this subject. To find out the views of ulama, in-depth interviews of leading Pakistani ulama belonging to all major schools of thought have been conducted. The study finds that many fears generated by early post 9/11 studies were rejected by the later ones. This study also finds that contrary to the common perception the leading ulama in Pakistan are open to the idea of madrasa reform but they prefer to do it internally as an ongoing process and not due to outside pressure. This study recommends that in order to resolve the madrasa problem in Pakistan, it is imperative to take into account the ideas and concerns of ulama running them. It is also important to take them on board in the fight against the religious militancy and terrorism in Pakistan.
\end{abstract}

Keywords: Madrasa, Perspectives, Militancy, Extremism, Violence, Ideology, Reforms, Ulama, Education, Religion

\section{Introduction}

Madaris in Pakistan became the focus of the world's attention after the catastrophic 9/11 incident. Despite the fact that none of the alleged attackers of the twin towers belonged to Pakistan or studied in madaris, these traditional institutions of learning became the focus of the world's attention as ' centers of religious militancy and radicalism'. Many studies were carried out by the Western as well as the local academics, journalists and government officials to establish links between the growing religious militancy and madrasa education in Pakistan. Many reports, articles and opinions were published in academic journals and print media. Initially, all pointed out the role of madrasa education in propagating religious violence and anti West sentiment among the Muslim youth. These studies issued warnings, alarmed the public about the 'menace of madrasas' in their society and demanded reform of madrasa education.

The perceptions about Pakistani madrasas as expressed by Western media and academia immediately after $9 / 11$ incident, have been aptly summarized by Nasr in the following words; "The violent attack of 9/11 convinced the Western world especially Americans that the problem with the Muslim world is that it is 'unenlightened' which means that it is pre Renaissance in its mindset. Due to their own historical experience many perceived that the Islamic world is in need of a Religious Reformation. Islamic Madrasas were 
perceived as the places where traditional, obsolete teachings indoctrinate dangerous values to the young minds."

Western media as well as government officials propagated this image of the madrasa. In a memo leaked to the media in Oct 2003, Donald Rumsfeld, US Secretary of Defence wrote; "Are we capturing, killing or deterring and dissuading more terrorists every day than the madrassas and the radical clerics are recruiting, training and deploying against us?"2

In an interview to Fox News in November 2003, he declared; "there's little places around the world where radical, extremist clerics are teaching young men and women to become suicide bombers and to go out and kill innocent men, women and children...". In the same interview, he presented his ideas to reform madrasa education, pointing out the need to engage in a 'battle of ideas', encouraging young Muslims to learn science, math, language so that they can earn a respectable living.

Various think tanks and government agencies published reports and recommendations to resolve the 'madrasa problem'. The World Bank, United States Agency for International Development (USAID), US Institute of Peace, the International Crisis Group (ICG), RAND Corporation, Congress, Pentagon and numerous European agencies joined this campaign. Later, many Pakistani writers, journalists and academics also jumped in and confirmed Western fears.

The Brookings Institution, a leading American think tank published an analysis paper on Pakistani Madaris in 2001 written by P.W. Singer. The paper stated that although religious education is an internal affair of the Pakistani government, the United States does have concerns about it as it has been 'highjacked by the extremists'. ${ }^{4}$ The report described a 'complete change' in traditional madrasa education during the 1980s as the Zia regime sought the support of religious groups for political gains and the war in Afghanistan led to mushroom growth of these institutions which accommodated millions of Afghan refugees and became involved in a radical jihad movement with the support of the US government. According to Singer, this development had dangerous repercussions as many madaris became affiliated with extremist religious/political groups and started teaching violence and hatred. About such madaris, Singer states: "These schools teach a distorted view of Islam. Hatred is permissible, jihad allows the murder of innocents, and the new heroes are terrorists. Martyrdom through suicide attacks are also extolled, and anti-western speeches are committed to memory. The students are uneducated, young, dependent on the schools, and cut off from contact with their parents for years at a time, and thus highly susceptible to being programmed toward violence."

The report advocated registration and regulation of Pakistani madaris by the government, and strengthening public education system in the country. The US government was urged to support Pakistan government in this regard. It was termed as 'a new cultural war' which had to be won.

\footnotetext{
${ }^{1}$ Syed Vali Nasr, The Rise of Sunni Militancy in Pakistan: the Changing role of Islamism and the Ulama in Society and Politics, (Oxford; Oxford University Press, 2010).

${ }^{2}$ USA Today.com; October 16, 2003; from Donald Rumsfeld, retrieved July 12, 2013

${ }^{3} \mathrm{http}: / / \mathrm{www}$.foxnews.com/story/2003/11/02/transcript-donald-rumsfeld-on-fox-newssunday/\#ixzz2YoUPZTvd

${ }^{4}$ P.W. Singer, Pakistani Madrasas ; Ensuring a System of Education not Jihad ,Analysis Paper \# 14.(Washington DC: The Brookings Institution , 2001).
} 
The International Crisis Group published a detailed report about the Pakistani madaris in July 2002 titled Pakistan: Madrasas, Extremism and Military. The report traces the history of madrasas in Pakistan and notices the exponential growth in madrasa numbers during the 1980s, a phenomenon described as 'the Madrasa Boom' in the report. Madaris were termed as the 'supply line of jihad' against the Soviets. It notices that violence in the name of religion neither originated in madrasas nor is this their defining characteristic. Majority of the madrasas do not advocate violence. Those who are associated with jihad and sectarianism are few and instantly recognizable. It is noted that pro jihadi madrasas only play a supporting role mainly as 'recruiting ground for militant movements'. It is more of an ideological affiliation than direct involvement. ${ }^{5}$

The Crisis Group Report takes into account the role America played in promoting the jihadi culture in madaris during the 1980s Afghan War. It states that US and Pakistan's Inter Services Intelligence sponsored not only Afghan jihad but also internal sectarianism. The message of jihad was targeted at the Soviets. The Muslims were told through madaris that participation in the Holy War was their sacred duty. There were special text books published by Center for Afghan Studies in the University of NebraskaOmaha which was funded by USAID. These books were written in Pashto and Dari by American and Afghan experts. The aim was to promote militant jihad among the Afghan youth. Basic math was taught by counting dead Russians and Kalashinkov rifles. ${ }^{6}$ University of Nebraska was paid US\$ 51 million from 1984 to 1994 for this project. The textbooks designed for promoting militancy in young minds were distributed among the displaced Afghans. Over 13 million copies were distributed in Afghan refugee camps and Pakistani madaris where many of their children studied. These books continued to be read by students even after the war ended. The Taliban found them useful as well. The report admits that traditional text of madaris does not include militant jihadi content. Afghan jihad and later Kashmir struggle brought the militant elements in madaris.

Hussain Haqqani, a prominent Pakistani journalist and later ambassador to the United States termed Pakistani madaris as 'Islam's Medieval Outposts' in an article published in Foreign Policy magazine in November 2002. The article confirmed Western fears by narrating the stories of madrasa students and teachers emphasizing their conservative mindset. It describes visits to different Pakistani madrasas by the author including Darul Ulum Haqqania, Akora Khatak, which has been described as a 'University of Jihad', a place which gives birth to the likes of Mullah Umar. ${ }^{7}$

Madrassas in Pakistan, an article by Suba Chandran was published in 2003 by the Institute of Peace and Conflict Studies in India. The author explains that after the end of Afghan war, madrasas and militancy continued to flourish in Pakistan because of the states changed policy on Kashmir. The jihad in Kashmir, the rise of the Taliban and the failing education system in the country led to an exponential growth of madaris. The author recommends that madaris have to be regulated, their funding should be controlled and their education must be reformed to control the menace of militancy. ${ }^{8}$

The US official 9/11Commission Report published in 2004 specifically mentioned the role of Pakistani madrasas in spreading violent ideologies. The report stated that

\footnotetext{
${ }^{5}$ International Crisis Group Pakistan; Madrasa, Extremism and the Military. Asia Report No.36, (29 July, 2002).

${ }^{6}$ Ibid

${ }^{7}$ Hussain Haqqani, "Islam's Medieval Outposts," Foreign Policy, Nov 1, 2002.

${ }^{8}$ Suba Chandran, "Madrasas in Pakistan", Institute of Peace and Conflict Studies (Sep 2003).
} 
although 9/11 was a shock for the United States, it was not a surprise. Islamist extremism had not concealed its intention of hurting the interests of the West. While identifying the enemy, the report traces the roots of extremism in Afgan jihad.

"We now know that these attacks were carried out by various groups of Islamist extremists. The 9/11 attack was driven by Usama Bin Ladin..... Bin Ladin also stresses grievances against the United States widely shared in the Muslim world".

The report recommends a global strategy against Al Qaeda in which their ideological support base has to be eliminated in order to reduce its impact.

"The enemy goes beyond al Qaeda to include the radical ideological movement, inspired in part by al Qaeda, that has spawned other terrorist groups and violence. Thus our strategy must match our means to two ends: dismantling the al Qaeda network and, in the long term, prevailing over the ideology that contributes to Islamist terrorism...

..Root out sanctuaries. The U.S. government should identify and prioritize actual or potential terrorist sanctuaries and have realistic country or regional strategies for each,.."

The Pakistani madaris have been termed as the 'incubators of violent extremism', which breed terrorism and supply motivated warriors. Donald Rumsfeld, US Secretary of Defence, is quoted in the report, asking; "Is enough being done to fashion a broad integrated plan to stop the next generation of the terrorists?"I0

The US Congressional Research Service (CRS) published a report on Education Reforms in Pakistan in December 2004. It expressed concerns about the poor state of Pakistan's public education and described US interest and investment in Pakistani education. The report stated that USAID signed a $\$ 100$ million five year bilateral agreement with the Pakistani government in 2002 to improve the quality of education in the country. It also stated that the government of Pakistan assured them that they will modernize the curriculum in religious madaris and will crack down on the ones involved in militant activities. ${ }^{11}$

A 2004 Report by A.H. Nayyar on the state of Pakistani education expressed concerns about the radical ideologies spread by madaris. The writer also expressed concerns about mainstream education in Pakistani schools and the widespread national myths created by the official textbooks, contributing to growing religious radicalism in society. ${ }^{12}$

In 2005, Indian author Sushant Sareen wrote a book on the subject with the title 'The Jihad Factory; Pakistan's Islamic Revolution in the Making'. She emphasized the link between jihadis and Kashmir issue, gave detailed profiles of Pakistani jihadi organizations and the role of madaris in making them. ${ }^{13}$

In 2007, Paul M.P. Bell from US Naval Post Graduate School, titled his thesis paper 'Pakistan's Madrassas; Weapons of Mass Instruction?' He traced links of Pakistani madaris with 9/11incident and July 7, London bombing, recommending education reform in Pakistan. He also pointed out that traditional madaris closed the door of 'independent

9 9/11 Commission Report (2004). Final Report of the National Commission on Terrorist Attacks upon the United States. Official Government Edition.

${ }^{10}$ Ibid

${ }^{11}$ K.A.Kronstadt, "Education Reform in Pakistan", CRS Report for Congress Dec 23, 2004

${ }^{12}$ A.H. Nayyar, "The Subtle Subversion" in The State of Curricula and Textbooks in Pakista, ed. A. Salim et al (SDPI, 2004).

${ }^{13}$ Sushant Sareen, The Jihad Factory; Pakistan's Islamic Revolution in the Making (New Delhi: Har Anand Publications, 2005) 
reasoning' (ijtihad) long ago, a fact which according to him, became a major reason for madaris' conservative attitude towards science and modernity. ${ }^{14}$

Pakistani mainstream media also began to express such concerns, especially during the Jamia Hafsa episode in 2007. Daily Jang, the newspaper with the largest circulation in Pakistan published many articles on the subject of madrasa reform during this time. Irshad Ahmed Haqqani, the late columnist, in an article published in July 2007, wrote about the need to bring the madaris out of the medieval times and make them enter the $21^{\text {st }}$ century. He expressed hopelessness stating that madaris are resistant to change and they will not accept reform. ${ }^{15}$

\section{Later Perspectives}

The initial perceptions about Pakistani madrasa, especially in the Western media and academia altered with time. The desperate search for the unidentified attacker and incomprehensible causes of the 9/11 attack led to hasty conclusions, simplified answers, distortion of facts and ground realities. The 'myth' created around the Islamic madrasas and their medieval education gradually began to break. New searches revealed new facts. Many sweeping statements and easy generalizations about madrasa education in Pakistan did not seem to fit in the newly found facts. Questions were raised about the earlier assumptions. It was realized that the truth is far more complicated.

This twist in the Western perceptions about Pakistani madaris began roughly around 2005 when numerous studies showing alternative facts began to appear. With time, many research projects and papers challenged the earlier studies presenting a different story about Pakistani madaris. This shift in Western and local understanding of madrasa education raised new questions about madrasas and the correct way to deal with them. A brief review of these new studies has been presented below.

The Madrasa Scapegoat by Peter Bergen and Swati Pandey published in Washington Quarterly in 2006 openly challenged the earlier perceptions about madrasas. The report stated that madrasas have become a symbol inviting condemnation and fears among the Western policy makers. Citing Donald Rumsfeld and 9/11 Commission Report, Pandey and Bergen pointed out that out of 79 terrorists involved in recent attacks in New York, Africa, London and Bali, only a few had ever visited a madrasa. Many of them had university degrees. This raises questions about what kind of education contributes to terrorism.

“....madrassas are less closely correlated with producing terrorists than are Western colleges, where students from abroad may feel alienated or oppressed and may turn toward militant Islam.

Given that 27 percent of the group attended Western schools, nearly three times as many as attended madrassas, our sample seems to confirm this trend. The data also show a strong correlation between technical education and terrorism, suggesting that perpetrating large-scale attacks requires not only a college education but also a facility with technology. This type of education is simply not available at the vast majority of madrasas." 16

\footnotetext{
${ }^{14}$ M.P. Bell, Pakistan's Madrassas; Weapons of Mass Instruction? (MS diss., Naval Post Graduate School, California, 2007).

${ }^{15}$ Irshad Ahmed Haqqani, "Dini Madaris aur unka Fehm-e-Islam, Koi Tabdili Mumkin Nahin,” Daily Jang, July 18, 2007.

${ }^{16}$ Peter Bergen and Swati Pandey, “The Madrasa Scapegoat,” Washington Quarterly, Spring 2006.
} 
The 'truth about terrorist education', according to this report is, that terrorism is not linked to madrasas and therefore they need not be a national security concern for the United States. Detailed accounts of recent terrorist attacks have been presented in this report. The origins of terrorists involved in these attacks have been traced. No links were found between madrasas and terrorism.

One obvious reason for this fact is stated as the absence of capacity in madrasa students to carry out an effective terrorist attack;

"Because madrasas generally cannot produce the skilled terrorists capable of committing or organizing attacks in Western countries, they should not be a national security concern. Conceiving of them as such will lead to ineffective policies, and cracking down on madrasas may even harm the allies that Washington attempts to help. In countries such as Pakistan, where madrasas play a significant role in education, particularly in rural areas, the wholesale closure of madrasas may only damage the educational system and further increase regional tensions."

This study suggested that instead of cracking down on Pakistani madrasas, the Western countries should monitor the activities of Islamic centers in their urban areas.

Another aspect of madrasa reform rhetoric was challenged by Hartung in his study 'Reform of the Indian Madrasa?' published in 2006. Hartung writes that the Western policy makers demand greater government control over madaris assuming that it was due to the independent status of madrasa that they were able to get away with violent activities. Strict government control would prevent them from doing so. Registration and regulation of madrasa by state was the foremost demand of the reform campaign. It must be recognized that most madaris that participated in Afghan jihad and later developed extremist tendencies were the ones funded by Saudi Arabia. The fact which is overlooked here is that the same madaris were closest to the official circles. In Saudi Arabia, for example, the most radical madaris are state sponsored. So lack of state control is not an issue to be concerned about. ${ }^{17}$

In Pakistan as well it was under state patronage that many madaris became involved in Afghan and Kashmir jihad.

Another study done during the same year, 'The Indian Madaris and the Agenda of Reform' by Yoginder Sikand (2006) differentiates between objectives of madrasa and mainstream education. It reminds the audience that the purpose of madrasa education is "providing Muslims with specifically religious education and transmitting the Islamic scholarly tradition. Madrasa education should not be judged by external goals but the ones set by the ulama themselves. It must be remembered that the aim of madrasa education is different from that of the modern school."

" The critics tend to see the madaris in stereo typical terms, often branding all madaris as backward and reactionary.... They are seen as a major burden on Muslim society... Much of what they teach is considered 'useless' in contemporary context.",

Such criticism of madaris has been termed as exaggerated. Claims that all madaris are static are grossly misleading. Madaris see themselves as guardian of the old tradition. This is the role that they are playing effectively and this is the main focus of their teachings.

\footnotetext{
${ }^{17}$ J.P. Hartung and H. Reifeld, Islamic Education, Diversity, and National Identity (New Delhi: Sage Publications, 2006).

${ }^{18}$ Yoginder Sikand, "The Indian Madaris and the Agenda of Reform," in Islamic Education, Diversity, and National Identity (New Delhi: Sage Publications, 2006).
} 
In 2008, a major study conducted by Christian Fair was published as a book titled 'The Madrasa Challenge; Militancy and Religious Education in Pakistan'. The study presents a detailed account of the madrasa education system in Pakistan. The structure of madrasa education and curriculum is discussed at some length. The enrollment figures in madaris are also presented. The study finds that contrary to the earlier assertions the madrasa enrollment figures in Pakistan are not alarming.

"The most generous estimates put full time madrasa enrollment well below $10 \%$.and most conservative estimates suggest that it is below $1 \% .{ }^{19}$,

The book states that various studies reject the idea that madaris are directly related to militancy.

It also suggests that contrary to the common perception, madaris might not simply produce terrorists rather the intolerant families might choose madaris. Madrasa enrollment trends indicate that most Pakistani parents prefer to send their children to private schools if that option is available in their locality. Many families who choose madaris do it not because of poverty but for ideological considerations. The mainstream schools of thought and the madaris being run by them are discussed in detail. It concludes that Pakistan hosts a diverse range of religious education. Unlike the popular perceptions, madaris do engage in rigorous scholarly activity. Many of them have close ties with religious political parties. Madaris in the tribal belt of Pakistan do supply suicide attackers in Afghanistan. Terrorists are recruited from such madaris. But since a small number of the population attends such madaris, they have little connection to international terrorism. ${ }^{20}$

This study recommends that international community must not make madrasa reform the focus of its policy. Pakistan's public institutions must receive the attention of the world. Investment should be made in public schools instead of madrasa reforms. If better options are available to the parents, they might not choose a madrasa for their children's education.

Christopher Candland's study "Pakistan's Recent Experience in Reforming Islamic Education" published in 2008 presents a thorough review of the reform effort in Pakistan. The study begins with relating the fact that just a decade ago, the whole world used to praise Islamic seminaries in Pakistan for their contribution in Afghan jihad. After 9/11, there was considerable pressure on the Pakistani government to monitor the activities of these schools and reform their education system. The government issued two ordinances to establish model madaris and regulate the affairs of regular madaris.

The study goes on to describe the controversy regarding the madrasa enrolment as the earlier figures were strongly contested by the later. The World Bank study presented figures which were far lower than the earlier estimates. Some sources that conducted the statistical studies might be considered more reliable by one scholar and might not be considered accurate by the other.

According to Candland, unlike the common perception, many madaris do have a desire to reform and update their curriculum. Many madaris agreed to get registered and affiliated with the Government Madaris board. Many prominent madaris became affiliated with the board but government efforts to control their affairs were not tolerated

\footnotetext{
${ }^{19}$ Christian Fair. The Madrassah Challenge (Washington DC: United States Institute for Peace Press, 2008).
}

${ }^{20}$ Ibid. 
by the ulama. An association of madaris with the name Ittehad Tanzimat-i-Madaris Diniya, Religious Madaris Organizations Alliance, was formed to protect the interests of the madaris and curtail government interference. This alliance represents at least 15000 madaris. ${ }^{21}$

The writer concluded that the reform effort based on the assumption that religious education be removed from the national curriculum is impractical. Such efforts imposed by force shall not enhance tolerance in society but would be counterproductive. Instead more importance should be given to religious education and dini madaris. With better funding, religious values of tolerance should be promoted. Better qualified, moderate ulama should be supported. Sectarianism should be discouraged. The Islamic message of peace should be highlighted.

Busting Pakistan's "Madrasa Myth," an article published in 2010 by Graff and Winthrop, as the name suggest, reinforces the scholars' view that the earlier 'myth' about madrasas in Pakistan was largely exaggerated. The continued attention of the world's media on Pakistan's religious schools was therefore misguided. The article says that education whether public, private or religious is not the main cause of militancy in Pakistan. The overwhelming focus on madaris has been aptly described by Pandey and Bergen as a scapegoat. The real causes of militancy are ignored. ${ }^{22}$

A major study by Brookings Institution's Center for Universal Education thoroughly investigated the problem of militancy and its links with education in Pakistan. Winthrop and Graff presented a new argument in this study which many earlier studies had been pointing out. Beyond Madrasas: Assessing the Links between Education and Militancy in Pakistan, published in 2010 makes a case for enhancing good education opportunities, improving quality of general education to reduce militancy. It is not religious education but the absence of any education which causes conflict and militancy. This argument has been supported by empirical evidence and statistics. The paper suggests that although the concerns about militancy in madaris had been partly justified, ignoring the big picture of Pakistan's public education condition has been a grave mistake which has led to misguided policy making and funds allocation.

According to this report, public education in Pakistan is a real cause for concern. The government of Pakistan completely failed to meet its targets and fulfill its lofty goals. The number of illiterate people in Pakistan is close to 47 million, this can go up to 50 million by 2015 . These figures should be the real cause of concern for the policy makers. There are big gaps and huge disparity among different sections of the society causing unrest. The government is mainly responsible for this state of affairs.

The conclusion this study draws is that contrary to the common perception the madaris education is 'at par' with education in other schools of Pakistan. The low standards of education, the disparity between different classes, poor teaching methods, obsolete curriculum is a common feature in public schooling as well. Madaris are not the sole problem. The policy of focusing on madaris alone must be changed.

${ }^{21}$ Christopher Candland, "Religious Education and Violence in Pakistan," (2005).

${ }^{22}$ Corinne Graff \& Rebecca Winthrop, "Busting Pakistan's Madrasa Myth,” Foreign Policy. July 1, 2010. 
"In light of these findings, the almost exclusive focus on madrasas as a security challenge-which is especially prevalent in the West-needs to be corrected? ${ }^{23}$ ",

Two important studies published in 2011 by Tahir Andrabi, Jishnu Das and Asim Khwaja of Harvard University, completely alter the earlier perspective on Pakistani madaris. They challenge the statistics on madaris presented in earlier studies.

Madrasa Metrics; the Statistics and Rhetoric of Religious Enrollment in Pakistan and The Madrasa Controversy; The Story Does Not Fit the Facts present groundbreaking work on madrasa controversy.

The former study challenges the assertions in different reports warning growing number of madrasa schools and enrollment in Pakistan. The writer wonders why such an important issue was reported without the backing of authentic research and survey. This paper is based on authentic data sources and reveals that earlier figures of madrasa enrolment were 'inflated by an order of magnitude'. Many other findings of this survey also contradict earlier reports. Instead of madrasas, it is the private schools which have grown in number and enrollment in Pakistan. ${ }^{24}$

This study also critically evaluates the reports on madrasa saying that many ideas presented in such investigations were based on weak evidences. The 9/11 Commission Report has also been criticized for relying on laymans interviews and not on authentic sources.

\section{Responses of Ulama}

The response of the ulama belonging to the five main wafaqs (boards) representing five main schools of thought in Pakistan, on government's madrasa reform campaign have been recorded for this study. In- depth interviews of ulama have been carried out and their views on various aspects of the post 9/11 madrasa reform campaign have been recorded. Selected parts of these interviews have been listed below.

\section{The Role of Pakistani Madaris during the 1980s Afghan Jihad Allama Khalil-ur Rehman Qadri, Nazim-i-Aala Jamia Islamia, Johar Town Lahore}

\section{Representative Tanzeem al Madaris Ahl-i-Sunnat (Hanafi Barelwi School)}

The attempt to link dini madaris with jihad in Afghanistan is also a result of the influence of Western propaganda. Madrasas are working on the same pattern since 1947. They are only concerned with education and training (taleem-o-tarbiat) of their students which results in the making of people who manage mosques, perform religious duties, conduct research in religious studies.

When Afghan refugees came to Pakistan in 1980s, they were welcomed by the people of Pakistan. Dini madaris also welcomed them and accommodated them in the spirit of brotherhood. These refugees included teachers and students who were adjusted in Pakistani madaris. Later, after the defeat of the Soviets when the fight continued, the same people went to fight in Afghanistan. In our opinion, it is the fight for their independence and survival.

\footnotetext{
${ }^{23}$ Rebecca Winthrop and Corinne Graff, Beyond Madrasas: Assessing the Links between Education and Militancy in Pakistan. Working Paper 2 (Brookings Centre for Universal Education, 2010).

${ }^{24}$ Tahir Andrabi et al. The Madrasa Controversy; The Story Does Not Fit the Facts (Pomona College, 2011).
} 


\section{Maulana Mufti Qari Muhammad Yousaf, Punjab University, Lahore}

\section{Representative of Wafaq Madaris al Arabia (Deobandi School)}

At that time (1980s), the Americans needed the madaris for their interest. Pakistani and American governments used madaris to win the war in Afghanistan against the Soviets. The mujahideen did not have any link with these madaris other than religious link. Madaris accommodated and supported mujahideen because they considered it their religious obligation. Initially, the mujahideen began their struggle against the mighty Soviets with meager resources and weapons. It was only later, after they had achieved initial successes that the Americans noted that they are capable of defeating the Soviets. It was then that they decided to support them. Mujahideen accepted this assistance from the US because they considered it legitimate to use whatever means are available to them for their defence.

\section{Maulana Abdul Malik, Muhtamim Jamia Markaz-e-Ulum Islmia Mansura, Multan Road, Lahore. \\ Rabta al Madaris al Islamia (Jamat-I-Islami) Representative of Jamat-i-Islami Pakistan}

There was no major change in the character of madaris during the 1980s. They were playing the same traditional role of upholding the Islamic values and education in the society. Only this traditional role was strengthened during this decade, when Afghan refugees came here and joined Pakistani madaris. The number of madaris grew due to this reason. Moreover, when UGC recognized madaris degrees as equivalent to M.A. Arabic or Islamiyat, the common people also became interested in madrasa education. Conequently, their scope and number grew.

Some madaris students took part in Afghan jihad on their own initiative. Madaris did not make themselves the centers of jihad. Religious organizations also did not get directly involved in jihad. But they did support the mujahideen's effort morally and financially. Jihad in Afghanistan was purely an Afghan struggle but the Muslims all over the world, especially the Arab Muslims, supported this struggle of their Afghan brothers. Many came to Afghanistan including Osama bin Laden. Wherever in the world the Muslims are in trouble, Muslims in different parts of the world feel for them and try their best to help them.

The American occupation of Afghanistan was also illegal. The world does not raise questions about this illegal occupation and American terrorism. But they do raise questions about madaris involvement in jihad. The Soviet occupation was unjustified, so is the occupation of the Americans. The former ended and the latter is also going to end soon. Currently, America is negotiating with the Taliban so that they may get a safe and respectful exit from Afghanistan.

\section{Dr. Allama Muhammad Hussain Akbar Chief Patron Idara Minhaj-ul-Hussain, Johar Town, Lahore}

The 1979 Iranian revolution inspired the whole Muslim world. People in Pakistan were also affected by this strong movement in their neighborhood. It strengthened Muslim freedom struggles throughout the world. It was during this time that the Soviets attacked Afghanistan. The Soviet system was based on atheist beliefs. In order to contain its influence, Islamist organizations all over the world became active. The US was also 
supporting the cause of mujahideen during this time because it suited their interests. Ulama and madrasa students also actively participated in this war. Mostly, the madrasas from Deoband School participated in this war. The Government of Pakistan was also involved in this war. As a result of this war, the Soviet Union disintegrated. Imam Khomeni predicted this event in his last letter to Gorbachev. He also invited him to accept Islam in this letter.

The negative repercussions of Afghan jihad continue to this day. We are all facing its dangerous fallout.

\section{Dr. Hasan Madni, Nazim-i-Aala Jamia Rahmania, Garden Town, Lahore Representative of Wafaq al Madaris al Salfia (Ahl-I-Hadith School)}

One thing has to be made clear here. US did not initiate the Afghan jihad. It was initiated by the Afghan Mujahideen. They were already engaged in war when Americans decided to intervene.

The role of madaris in the Afghan war was the propagation of this ideology. When madrasas enjoyed state support, they were empowered. Their position became better. During the Afghan jihad, madaris trained leaders who fought in the jihad. At that time, it was the Americans who were supporting the jihad. They were the ones who brought Osama bin Laden to Afghanistan. Later, they were the ones who took a $U$ turn, not madaris or ulama.

\section{About the post 9/11 Western demand for madrasa reform in Pakistan}

\section{Dr. Hasan Madni}

The $20^{\text {th }}$ century was the century of the wars between the Western powers. After the cold war, a new world order was established in the world. The notions of the "clash of civilizations' were promoted in this unipolar world. The United States never took part in World War I and II. After the cold war, they deliberately created an enemy for two basic reasons; first, the US war and weapons industry needed conflict in the world. Secondly, the US needed a common enemy to stay united, as it consists of many different states and many different cultures.

\section{Dr. Allama Muhammad Hussain Akbar}

The US and its Western allies had seen the ideological and intellectual strength of dini madaris. The felt threatened by this force. Although most students who participated in jihad came back to madaris after the war was over but some of them became agents of external international powers. They became involved in armed struggle in the name of religion.

\section{Maulana Mufti Qari Muhammad Yousaf}

Madaris never had links with militancy. They were concerned with education. The US government felt threatened with the implementation of Islamic laws and government in Afghanistan back in 1990s. It was a system challenging their imperialist system based on greed. The Taliban government would run government affairs with meager resources. It was unlike the system of government anywhere in the world. Our cricket team would have more budget than the total budget of the Taliban government. This was a clear challenge to the capitalist greed based system. That is why they created the drama of $9 / 11$ to make an excuse to curb this system. Now after 10 years it is hard for them to find a safe exit from here. 


\section{Why Pakistani Madaris are being Blamed for Spreading International Terrorism}

\section{Allama Khalil-ur Rehman Qadri}

In the 1990s, a kind of unity was being developed among ulama. United they were a force as they catered to approximately ten million students. This large number could bring change democratically without violence. They (state and the West) perceived this as a threat and wanted to control madrasas so that they do not activate. But this was just their perception. Madaris had no such intention. They were working on their own traditional agenda. It was just a threat perception.

\section{Dr. Hasan Madni}

Terrorism has never been defined clearly by the West. This term has no clear meaning. According to the Western people, anyone who is in minority and dares to take a different position than the majority is a terrorist. Anyone who refuses to accept the existing norms is a terrorist. This is how this term has been used by the West. Pakistan went for nuclear explosions in 1998. The US entered this region within two and a half years of that.

\section{Maulana Abdul Malik}

Americans use the term 'reforms' to take control of the madaris. Government also received huge amounts for this purpose. But Madaris had understood their scheme and together they rejected the government's interference in the name of reforms.Today Madaris are as free and independent as ever. Madaris did not accept the American dictation.

\section{Dr. Allama Muhammad Hussain Akbar}

US and its Western allies had seen the ideological and intellectual strength of dini madaris. They felt threatened by this force. Most students who participated in jihad came back to madaris after the war was over but some of them became agents of external international powers. They became involved in armed struggle in the name of religion.

Any real investigative report of the $9 / 11$ incident has not been made public. Many evidences point to very different facts than the official story. Besides, none of the alleged attackers of the twin towers were students of any religious madrasa. Despite this, madaris have been targeted as a prime suspect. The same madaris which helped US and Western powers against the Soviets were now declared terrorists. American interests changed. America feared the Islamists now.

\section{Measures Taken by Pakistani Government to Reform Madrasas after 9/11}

They asked us to establish madrasa boards despite the fact that we already had a comprehensive organization. There was an attempt to make an official government (sarkari) board but the Ulama wanted to continue following their own mechanism.

There was a demand to expel the foreign students. First they were asked to get NOC from their respective embassies. Later even those who got an NOC were kicked out.

I would like to share a very important piece of information here. In 2002, India had 1200 students studying in 911 madaris. During the next 5 years, 2500 new madaris were established. Many incentives were given to foreign students; they were encouraged to join madaris in India. It was on this basis that in 2007, India applied for the membership of OIC claiming that they have students from all over the Islamic world studying in India. 
When we were having a 'crack down' against the foreign students, India was welcoming them. Later they accused Pakistan that no foreign student stays there.

There was also demand for madrasa registration. Ulama had no objection to this demand. Many madaris got registered.

Another demand was the inclusion of modern subjects along with the religious subjects in the curriculum. This is also considered a correct demand by ulama. In fact, many of them already taught both types of subjects in their madaris before this reform campaign.We think it is important for students to understand social issues. Ulama agree with this demand of the government but we have strong reservations to their raiding madaris and expelling foreign students from the country.

\section{Dr. Allama Muhammad Hussain Akbar}

With the help of different agencies, investigations were carried out against the madaris. The purpose was to impose such a syllabus by force which damages the spirit of jihad in the Muslim youth.The aim was to suppress the religious mind. Different excuses were made to interfere in the affairs of madaris. Huge financial incentives were given. Provision of modern facilities was promised.Trained teachers were offered to teach modern subjects with modern methods. Initially, some naïve madaris were fooled into accepting such offers. But later the true intentions of these people were exposed when they started interfering in the madrasa affairs and threatened to withdraw their financial support in case madrasas do not comply. Even the madaris who initially fell prey to the Western designs, returned to their original traditional method.

It was alleged that dini madaris do not provide modern education. This is against the reality. Madaris do provide modern education but they do it according to their limited resources.Shia madaris admit only those students who have passed matriculation exams . Other Ahl-i-Sunnat madaris have also improved their education system with time. Computer education has been introduced in many madaris.But this used under strict supervision of the teachers. Islam is not against the modern education. But the aims of modernity at times are incompatible with Islam.

\section{Maulana Abdul Malik}

American reforms demand that jihad be excluded from the Quran and Hadis. The ayat of jihad should be taken out of the Quran. The ayat condemning Jews and Christians should also be excluded. All this is an old wish of the Jews which could neither be fulfilled in the past nor will it be fulfilled now.

\section{Maulana Mufti Qari Muhammad Yousaf}

The Musharraf government, pressed by the demands of the Western governments, ordered an immediate action against the madaris and bring all of them under the Ministry of Education. The Minister of Religious Affairs Dr. Mahmood Ahmed Ghazi was given the task to make a comprehensive report about the activities of these madaris within four months. Dr. Mahmood Ghazi told me himself that after four months, the report he had for Musharraf was that the work done by the madaris cannot be handled by the government. Without taking any help from the government, madaris are providing education, food and clothing to the poorest section of the society. The people giving them money for this job would stop paying them if they were brought under government control. Government would not be able to regulate such a big task. It would be a huge burden on the national 
resources. After this briefing Musharraf came to the television screen and admitted the contribution of madrasas as 'the largest NGO' working in Pakistan. From that moment onwards, the government practically stopped interfering in the affairs of madaris.

\title{
Response of Ulama to Madrasa Reform Campaign
}

\section{Maulana Mufti Qari Muhammad Yousaf}

The ulama have joined together, they insisted that allegations against madaris are baseless. We invite Western researchers to come, enter our madaris and then report about us. Many reports and surveys published in their journals are mere fabrication of facts and not based on ground realities.

\section{Allama Khalil ur Rahman Qadri}

There was demand for madrasa registration. Ulama had no objection to this demand. Many Madaris got registered.

Another demand was the inclusion of modern subjects along with the religious subjects in the curriculum. This is also considered a correct demand by ulama. In fact, many of them already taught both types of subjects in their madaris before this reform campaign. We think it is important for students to understand social issues. Ulama agree with this demand of the government but we have strong reservations to their raiding madaris and expelling foreign students from the country.

\section{Dr. Hasan Madni}

The government did not do much on the ground. They only made statements in the media. We did not face any pressure. Madaris continue to give their traditional education, their system has not been affected at all. However great damage has been done on the media, where the traditional role of madaris has been undermined, ridiculed and their image has been destroyed in the eyes of the public.

\section{Your personal opinion about the need to reform madrasa education in} Pakistan

\begin{abstract}
Allama Khalil-ur Rehman Qadri
In my opinion, modern subjects should be a part of madrasa curriculum but ground realities must be kept in mind in this respect. We cannot teach medicine or engineering in madrasas. We have our own system which is quite demanding. But I do think we should teach the basics of science and other subjects. We should pay special attention to the speaking skills of the students. Current affairs should also be taught in madaris.

I also think that inter-sect harmony should be promoted in Pakistani madaris. If we (madrasas) are blamed for sectarianism, it is justified. We must put a stop to the existing practice in madaris which promotes sectarian hatred.
\end{abstract}

\section{Dr. Hasan Madni}

Dini madaris are fulfilling about $30 \%-40 \%$ of their objectives. There is room for improvement.

Madaris were mainstream educational institutions in the past. They used to fulfill all the educational needs of society. There was no distinction between religious and secular 
education. With the advent of imperialism, a duality emerged in education. Religious education was separated from secular, modern education. Madaris were reduced to religious education alone. This is also a form of secularism. Today, both mainstream institutions and madaris are secular in this sense. They separate religion (din) from the world (dunya). The educational ideology of Islam does not differentiate between the two.

\section{Dr. Allama Muhammad Hussain Akbar}

Dini Madaris have a history. There was a time when a comprehensive system of education existed in madrasas under one roof. The graduates of these early madrasas would become scholars, Faqih, scientists, politicians, economists and experts in various different fields. This system of education was changed with the advent of the British imperialism. British occupied different parts of the world and gradually they divided the education system into two parts; religious and secular education. All resources were now spent on the propagation of the British education and interests. But despite all this, the ulama refused to surrender to the British might. They accepted hunger, thirst and poverty but did not compromise on their principles. They revived the Sunnah of Ashab-i-Suffah and continued their teaching and learning with meager resources.

With time, most worldly needs and resources were diverted towards the government. Many issues which madrasas dealt with became obsolete. Ulama continued research and teaching.

Later, many independence movements changed the environment of the imperial rule. A strong independence movement in the sub-continent resulted in the making of Pakistan. The basis of Pakistan was the ideology of Islam. The purpose of making this country was to acquire a land where the laws of God are implemented. Therefore, all constitutions of Pakistan have an Islamic spirit. The 1973 constitution also recognizes the sovereignty and power of Allah. Declaration of Qadianis as non Muslims is also a result of religious concerns of ulama and the people.

\section{Maulana Abdul Malik}

There is need for improvement in madaris. Madaris need to teach modern subjects at all levels like they teach the religious subjects. Madaris students must be kept aware of the current developments and languages. They should be given information about the Muslim world, their geography, natural resources, location, etc. Modern technology must be used for this purpose. We need to develop good representatives of the Muslim Ummah who can effectively raise their voice on important issues.

\section{Maulana Mufti Qari Muhammad Yousaf}

One must understand that there are about 18000 registered madaris in Pakistan where millions of students study. These students come after completing their primary level studies. They are taught Dars Nizami which consists of 25 subjects which have to be covered in 10 years. The teachers teach these subjects from dawn till dusk on a very low salary. The students come from the poorest section of the society. Now madaris teachers are expected to teach 25 subjects as well as the modern syllabus taught in universities to these lower class students with limited ability on an extremely low salary (the maximum they get is 10,000). What exactly are we asking from these poor souls? We should think about it. A university teacher gets an excellent salary and gets tired if he takes four classes in a day. These madrasa teachers are only human. 


\section{Your Recommendations for Reforming Madrasa Education Maulana Mufti Qari Muhammad Yousaf}

Let me share with you that on their own, the madaris have started teaching modern subjects in their limited capacity. We have madaris now where we are producing MBAs as well as Dars Nizami Graduates. In my own small madrasa, some students are studying medicine and engineering. But we tell them that this is just a source, the real knowledge is the one that builds characters and helps in the hereafter. Instead of people urging maulvis to learn modern subjects, it should be the other way around. People should learn some religion as well because it is important. The Faraiz and Wajbats should be taught in schools. Aren't they important for life? We have seen many examples of big bureaucrats, officers not able to recite Dua-i-Qanoot or Ayat-ul-Kursi properly. Why insist that a maulvi learn English or Math?

\section{Dr. Allama Muhammad Hussain Akbar}

Dini madaris are not provided any budget share from the government. They are working on self reliance basis. Examine the government educational institutions' performance on the other hand who receive government funds on regular basis. There are ghost schools but you will never find a ghost madrasa. Madaris are the largest NGO in the countrym catering to the needs of millions of Pakistani students.

I would especially like to mention here that the concerns expressed by the West about the lack of employment opportunities for madrasa students are not genuine. Don't be fooled when they call them sympathetically 'beycharey', 'maskeen', not able to earn a decent living.

I remember during one of my meetings with an American delegation, they were expressing deep sympathy for madrasa students. I assured them jokingly not to worry as 'no maulvi has ever died of hunger, however many might have died of overeating...' (Laughing) It is a fact.

Having said this, I do feel there is a need to reform education in all sectors after every five years on regular basis.

I do feel there is a need to improve relations with the West through dialogue. The door for dialogue is open in Islam till the very last moment. In Karbala, Imam Hussain kept on inviting the Yazidi Commandos for dialogue. We still have the place in Karbla where he held talks with Umar bin Saad at the last moment. Islam is a religion of peace. It is a religion of logic. That is why despite Western propaganda, it is the fastest growing religion in the world today.

\section{Conclusion}

The post 9/11 madrasa reform campaign by the government, international and local media, and academia failed to impact the Pakistani madaris mainly because the views of the ulama were largely ignored in this debate. The voice of ulama running the madaris was mostly absent from the extensive discourse on the subject of madrasa reform after 9/11. It was mainly due to this reason that despite spending huge amounts of money, loud rhetoric and media campaigns, nothing substantial could be achieved on the ground. It is hard to reform madrasa education and system in Pakistan without taking into consideration the concerns of ulama. For successful reform of madrasa education, ulama have to be taken on board, their problems have to be addressed, and they should be made partners in the efforts to root out militancy and religious extremism from the country. 


\section{Selected Bibliography}

1. Andrabi,Tahir. Jishnu Das and Asim Ijaz Khawaja., The Madrasa Controversy; The Story Does Not Fit the Facts. Pomona College, 2011.

2. Bell, M.P. Pakistan's Madrassas; Weapons of Mass Instruction? MS diss., Naval Post Graduate School, California, 2007.

3. Bergen, Peter and Swati Pandey, "The Madrasa Scapegoat," Washington Quarterly, Spring 2006.

4. Candland, Christopher. "Religious Education and Violence in Pakistan." (2005).

5. Chandran, Suba. "Madrasas in Pakistan", Institute of Peace and Conflict Studies (Sep 2003).

6. Fair, Christian. The Madrassah Challenge. Washington DC: United States Institute for Peace Press, 2008.

7. Graff, Corinne and Rebecca Winthrop. "Busting Pakistan's Madrasa Myth.” Foreign Policy. July1, 2010.

8. Haqqani, Hussain. "Islam's Medieval Outposts," Foreign Policy, Nov 1, 2002.

9. Haqqani, Irshad Ahmed. "Dini Madaris aur unka Fehm-e-Islam, Koi Tabdili Mumkin Nahin," (Urdu). Daily Jang, July 18, 2007.

10. Hartung, J.P. and H. Reifeld, Islamic Education, Diversity, and National Identity. New Delhi: Sage Publications, 2006.

11. International Crisis Group Pakistan; Madrasa, Extremism and the Military. Asia Repert No.36, (29 July, 2002).

12. Kronstadt, K. A. "Education Reform in Pakistan", CRS Report for Congress, Dec 23, 2004.

13. Nasr, Syed Vali. The Rise of Sunni Militancy in Pakistan: the Changing Role of Islamism and the Ulama in Society and Politics.Oxford; Oxford University Press, 2010.

14. Nayyar, A.H. "The Subtle Subversion" in The State of Curricula and Textbooks in Pakistan, ed. A. Salim et al (SDPI, 2004).

15. Sareen, Sushant. The Jihad Factory; Pakistan's Islamic Revolution in the Making. New Delhi: Har Anand Publications, 2005.

16. Sikand, Yoginder. "The Indian Madaris and the Agenda of Reform, in "Islamic Education, Diversity, and National Identity. New Delhi: Sage Publications, 2006.

17. Singer, P.W. Pakistani Madrasas; Ensuring a System of Education not Jihad. Analysis Paper 14 Washington DC: The Brookings Institution, 2001.

18. Winthrop, Rebecca and Corinne Graff, Beyond Madrasas: Assessing the Links between Education and Militancy in Pakistan. Working Paper 2, Brookings Centre for Universal Education, 2010.

19. 9/11 Commission Report (2004). Final Report of the National Commission on Terrorist Attacks upon the United States. Official Government Edition. 